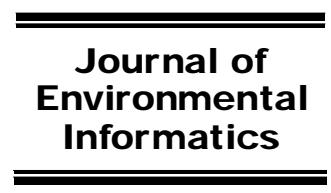

www.iseis.org/jei

\title{
Lab-Scale Experiment and Model Study on Enhanced Digestion of Wastewater Sludge using Bioelectrochemical Systems
}

\author{
J. R. Asztalos and Y. Kim* \\ Department of Civil Engineering, McMaster University, Hamilton, ON L8S 4L8, Canada
}

Received 28 January 2015; revised 19 March 2015; accepted 25 March 2015; published online 14 June 2016

\begin{abstract}
Anaerobic digestion is the slowest process in municipal wastewater treatment, requiring at least 15 days of SRT (solids retention time). Here, we implemented microbial electrolysis cells (MECs) in anaerobic digesters to shorten the long SRT requirement. The MEC bioanode oxidizes acetic acid while the cathode produces $\mathrm{H}_{2}$ gas. The electrode reactions can expedite acetic acid decomposition and thus enhance the rate of biosolids destruction because acetoclastic methanogenesis is known to be the rate-limiting step in conventional anaerobic digestion. A lab-scale electrically-assisted digester (EAD) with the MEC reactions was operated under a continuous fed-batch mode using raw wastewater sludge. Additionally, a steady-state model was developed by incorporating the MEC reaction in ADM1 (Anaerobic Digestion Model No.1 by International Water Association). In experiments, the EAD achieved 55\% VSS (volatile suspended solids) removal and 61\% COD (chemical oxygen demand) removal at a 6-day SRT while the control digester (built with the same electrode components but no MEC reactions induced) showed only 47\% VSS removal and 50\% COD removal. This result indicates that the SRT requirement can be substantially reduced by implementing the MEC reactions in mesophilic anaerobic digestion. Under a 14-day or 2-day SRT condition, however, the EAD did not show meaningful improvements on the COD and VSS removal compared to the control digester. Hydrogenotrophic methanogenesis was sufficiently rapid as $\mathrm{H}_{2}$ gas was not detected in produced biogas. The mathematical simulation results demonstrated that the MEC reactions substantially reduce acetic acid concentration and thus supplement the slow acetoclastic methanogenesis reaction.
\end{abstract}

Keywords: wastewater sludge digestion, mesophilic anaerobic digesters, bioelectrochemical systems, anaerobic digestion models, bioanode reaction models, exoelectrogenic bacteria, acetoclastic methanogenesis, energy recovery

\section{Introduction}

Mesophilic anaerobic digestion is the slowest process in municipal wastewater treatment. Anaerobic digestion, treating only 1\% of total wastewater volume, requires significantly large reactors to maintain a long retention time of $15 \sim 20$ days (Metcalf \& Eddy et al., 2003). As a result, construction and operation of anaerobic digesters are responsible for major expenses in wastewater treatment. The main objective of this study is to accelerate the rate of biosolids destruction so that the costs for anaerobic digestion can be reduced with smaller digester volumes and shorter solids retention times (SRT).

In mesophilic anaerobic digesters, destruction of biosolids is achieved through a series of biological reactions (Figure 1). Polymeric particulate organics (e.g., carbohydrates, proteins and lipids) are hydrolyzed into soluble organics (e.g., sugars, amino acids and long-chain fatty acids). Hydrolysis of carbohydrates and proteins are generally quick (1 3 days) while hydrolytic decomposition of lipids is relatively slow,

${ }^{*}$ Corresponding author. Tel.: +1 9055259140 ext. 24802.

E-mail address: younggy@mcmaster.ca (Y. Kim).

ISSN: 1726-2135 print/1684-8799 online

(C) 2017 ISEIS All rights reserved. doi: 10.3808/jei.201500308 taking $6 \sim 8$ days (Grady et al., 2011). Fermentation is usually fast, requiring only about 1 day for decomposition of sugars and amino acids into $\mathrm{H}_{2}$ gas and volatile fatty acids (Grady et al., 2011). Beta-oxidation (anaerobic oxidation) needs about 4 days to start converting long-chain fatty acids into $\mathrm{H}_{2}$ gas and acetic acid (Grady et al., 2011). The final step of biosolids destruction is driven by hydrogenotrophic and acetoclastic methanogens. Relatively rapid hydrogenotrophic methanogenesis starts oxidizing $\mathrm{H}_{2}$ gas and producing $\mathrm{CH}_{4}$ in about 1 day (Grady et al., 2011). However, acetoclastic methanogens grow slowly, requiring $3 \sim 5$ days for Methanosarcina species and at least 12 days for Methanosaeta species to start utilizing acetic acid for $\mathrm{CH}_{4}$ production (Grady et al., 2011). Approximately $70 \%$ of methanogenesis in anaerobic digestion is driven by acetoclastic methanogens (Grady et al., 2011), making acetoclastic methanogenesis the rate-limiting reaction for overall biosolids destruction. Also, the slowly growing Methanosaeta species are known to be more responsible than Methanosarcina species for the rate-limiting role of acetoclastic methanogenesis (Conklin et al., 2006). Hydrolysis can also be very slow when a large amount of lignocellulosic materials is present in sludge (Rittmann and McCarty, 2001). However, acetoclastic methanogenesis is often considered to be the ratedetermining reaction in domestic wastewater sludge digestion (Rittmann and McCarty, 2001; Grady et al., 2011). Thus, we 
focused mainly on mitigating the rate-limiting effect of acetoclastic methanogenesis in mesophilic anaerobic digesters.

In this work, we aimed to expedite the decomposition of acetic acid by implementing microbial electrolysis cells (MECs) in mesophilic anaerobic digesters. At the MEC bioanode, exoelectrogenic bacteria oxidize organic fatty acids (including acetic acid) and the MEC cathode produces $\mathrm{H}_{2}$ gas via electrolytic water reduction (Figure 1) (Liu et al., 2005b; Rozendal et al., 2006; Logan et al., 2008). $\mathrm{H}_{2}$ gas produced at the cathode will be rapidly utilized by hydrogenotrophic methanogens (Tice and Kim, 2014). As a result, the MEC reactions coupled with hydrogenotrophic methanogenesis can convert a certain fraction of acetic acid into $\mathrm{CH}_{4}$ gas, creating an additional reaction pathway for the rate-limiting acetic acid decomposition step in anaerobic digesters (Figure 1). Therefore, the MEC electrode reactions implemented in anaerobic digestion can enhance the rate of biosolids destruction. In addition, the rate of the MEC reactions can be monitored with electric current, allowing precise evaluation of their contribution to biosolids destruction.

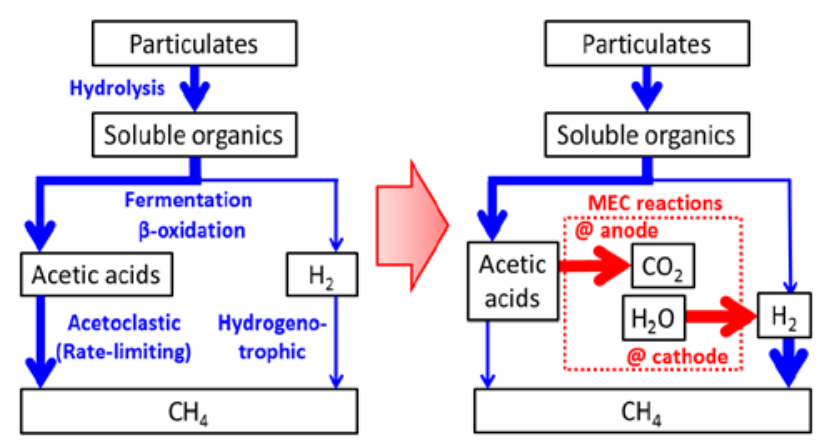

Figure 1. Changes in the reaction pathway for biosolids destruction by integrating the MEC reactions in anaerobic digestion. (MEC: microbial electrolysis cell)

The objective of this study is to demonstrate this new concept of integrating MEC technology with anaerobic digestion to expedite chemical oxygen demand (COD) and volatile suspended solids (VSS) removals. Eventually, we aimed to reduce the long SRT requirement of mesophilic anaerobic digesters and investigate how the shortened SRT conditions along with the MEC reactions affect other biological reactions, including acetoclastic and hydrogenotrophic methanogenesis. There are a number of previous studies where wastewater sludge or animal manure wastewater was treated in bioelectrochemical systems (Pham et al., 2006; Rodrigo et al., 2007; Tartakovsky et al., 2011; Liu et al., 2012; Lu et al., 2012; Ge et al., 2013; Guo et al., 2013; Tartakovsky et al., 2014). A recent study also showed enhanced $\mathrm{CH}_{4}$ production and decomposition of individual organic acids by implementing an MEC in an anaerobic digester (Liu et al., 2013). Sasaki et al. (2010; 2011; 2013) provided $\mathrm{H}_{2}$ gas by cathodic water electrolysis to enhance $\mathrm{CH}_{4}$ production from various waste biosolids. Also, high purity $\mathrm{CH}_{4}$ production (98.1\%) was achieved by coupling MECs in anaerobic digesters (Bo et al., 2014). In addition to these synergistic effects demonstrated in the previous stu- dies, we focused primarily on mitigating the rate-limiting role of acetoclastic methanogenesis in anaerobic digestion by introducing the additional acetic acid degradation pathway using MECs so that the long SRT requirement (15 days or longer) can be substantially shortened.

Another aspect of this study is to investigate the energy requirement since the MEC reactions are not spontaneously driven. The electric energy requirement of an MEC as an independent system is relatively small; thus, energy recovered as $\mathrm{H}_{2}$ gas is usually greater than the applied electric energy (Cheng and Logan, 2007; Call and Logan, 2008; Hu et al., 2008). However, municipal wastewater sludge has relatively low ionic conductivity ( $\sim 2 \mathrm{mS} / \mathrm{cm}$ ) that can result in high resistive energy losses. On the other hand, biogas production $\left(\mathrm{H}_{2}, \mathrm{CH}_{4}\right)$ is also driven by other biological reactions, such as fermentation, beta-oxidation (anaerobic oxidation) and methanogenesis; therefore, the energy recovery with these reactions can be higher than that with only the MEC reactions. With these multiple factors influencing the energy consumption and recovery, we investigated whether the proposed electricallyassisted digesters can be operated as a net energy producer by comparing the energy requirement and energy production.

In our experimental system where anaerobic digestion is coupled with an MEC, biosolids destruction is achieved by a number of reactions, including hydrolysis, fermentation, betaoxidation, acetoclastic methanogenesis, hydrogenotrophic methanogenesis, electrolysis at the MEC cathode and oxidation at the MEC bioanode. Thus, it is practically impossible to monitor all of the individual reactions in experiments. Thus, we employed a numerical model to keep track of individual component concentrations and biological reactions in our experimental system. Among various wastewater treatment models (Yeomans et al., 2003; Yang et al., 2006; Hao et al., 2013), as International Water Association's Anaerobic Digestion Model No. 1 (ADM1) is widely used in anaerobic digestion model studies (Batstone et al., 2002), we built ADM1 and incorporated the electrode reactions in the model. Model simulation results were provided in this study to support our hypothesis that the MEC reactions partially supplement the rate-limiting acetoclastic methanogenesis reaction in wastewater sludge destruction. The findings of this study will provide an improved method for wastewater sludge treatment using the MEC technology and approximate the energy requirement for enhanced sludge treatment.

\section{Material and Methods}

\subsection{Reactor Construction}

Two lab-scale anaerobic digester reactors, a control digester and an electrically-assisted digester (EAD), were constructed with MEC components in cylindrical polypropylene containers (total $250 \mathrm{~mL}$ with $240 \mathrm{~mL}$ of sludge volume and 10 $\mathrm{mL}$ of head volume) (Figure 2). Four carbon fiber brushes (2 $\mathrm{cm}$ diameter and $2.5 \mathrm{~cm}$ in length; Mill-Rose, $\mathrm{OH}$ ) were pretreated in a muffle furnace at $450{ }^{\circ} \mathrm{C}$ for 30 minutes (Wang et al., 2009) before they were located in each digester as bioanodes. Stainless steel mesh was used as the MEC cathode 
without any precious metal catalysts (total projected area of $150 \mathrm{~cm}^{2}$, AISI 304, 100-mesh, McMaster-Carr, OH). The stainless steel mesh was rolled into a two-layer cylinder and placed around the interior wall of the reactor (Figure 2B). Plastic mesh ( $1 \mathrm{~mm}$ thick) was placed between the anode brush and cathode to prevent electric short-circuiting. A nylon barbed tube fitting (McMaster-Carr, $\mathrm{OH}$ ) was glued to the top of the reactor and connected to a plastic tube to collect biogas as previously demonstrated (Call and Logan, 2008). Another barbed fitting was placed near the bottom of the reactor to feed the reactor and draw digested sludge.

\subsection{Reactor Operation}

The constructed digesters were inoculated with digested sludge effluent from a municipal wastewater treatment facility. After this one-time inoculation, the digesters were fed directly with a mixture of secondary ( $60 \%$ by volume) and primary ( $\sim 40 \%$ by volume) sludge collected from a nearby wastewater treatment facility. The collected sludge was stored at $4{ }^{\circ} \mathrm{C}$ and was unaltered by any pretreatments. The influent total COD and VSS in the feed sludge were consistent throughout the digester operation: influent COD $=21.60 \pm 1.70 \mathrm{~g} / \mathrm{L}$; and influent VSS $=11.98 \pm 1.29 \mathrm{~g} / \mathrm{L}$. The COD/VSS ratio of 1.80 is higher than 1.42, indicating that the influent sludge contains a relatively large amount of soluble COD.

The control reactor was operated as a typical mesophilic anaerobic digester without any electrode reactions by disconnecting the electrodes. The MEC reactions in the EAD were induced using an external power supplier (GPS-1850D; GW Instek, CA). The electric potential application $\left(E_{a p}\right)$ was constant at $1.2 \mathrm{~V}$ in experiments while $0.6 \mathrm{~V}$ was applied during the start-up period. Both digesters were operated in a bench-top chamber at a constant temperature $\left(39.4 \pm 1.2^{\circ} \mathrm{C}\right)$. Note that this temperature condition is commonly applied in conventional mesophilic anaerobic digestion of municipal wa- stewater sludge (Metcalf \& Eddy et al., 2003). Both digesters were continuously mixed using magnetic stirrers.

For a given SRT condition, the lab-scale digesters were operated under a continuous fed-batch mode where $120 \mathrm{~mL}$ (one half of the sludge volume) was regularly replaced with raw sludge. For instance, a 14-day SRT condition was achieved by feeding the digester every 7 days. Three different SRT conditions (14, 6 and 2 days) were examined. The digesters were operated for $\sim 4$ months (including the start-up period). The initial SRT was 14 days and was shortened down to 6 days and then 2 days. For each SRT condition, at least 4 fedbatch cycles were repeated and results from the last 3 fed-batch cycles were taken for discussion.

\subsection{Experimental Measurements}

For each fed-batch cycle, raw and digested sludge samples were measured for total suspended solids (TSS), volatile suspended solids (VSS) and total chemical oxygen demand (COD) in accordance with the standard methods (Eaton et al., 2005). Conductivity and $\mathrm{pH}$ were measured using a $\mathrm{pH}$ and conductivity meter (SevenMulti, Mettler Toledo, Switzerland). The raw sludge $\mathrm{pH}$ was stable at $\mathrm{pH} 6.4 \pm 0.2$ throughout the experiment. The conductivity of raw sludge was relatively low at $2.2 \pm 0.3 \mathrm{mS} / \mathrm{cm}$.

Electric current in the EAD $(I)$ was determined by measuring the electric potential drop across a $10-\Omega$ resistor every 20 minutes using a multimeter and data acquisition system (Model 2700, Keithley Instruments, OH). Electric current (I) was normalized by the sludge volume in the reactor $(240 \mathrm{~mL})$ to calculate the volume-based current density (or specific current).

Biogas produced in each digester was collected using a gas bag (3 L capacity, Cali-5-Bond, Calibrated Instrument Inc., $\mathrm{NY}$ ). Collected gas was analyzed for $\mathrm{CH}_{4}, \mathrm{CO}_{2}, \mathrm{~N}_{2}, \mathrm{O}_{2}$ and $\mathrm{H}_{2}$

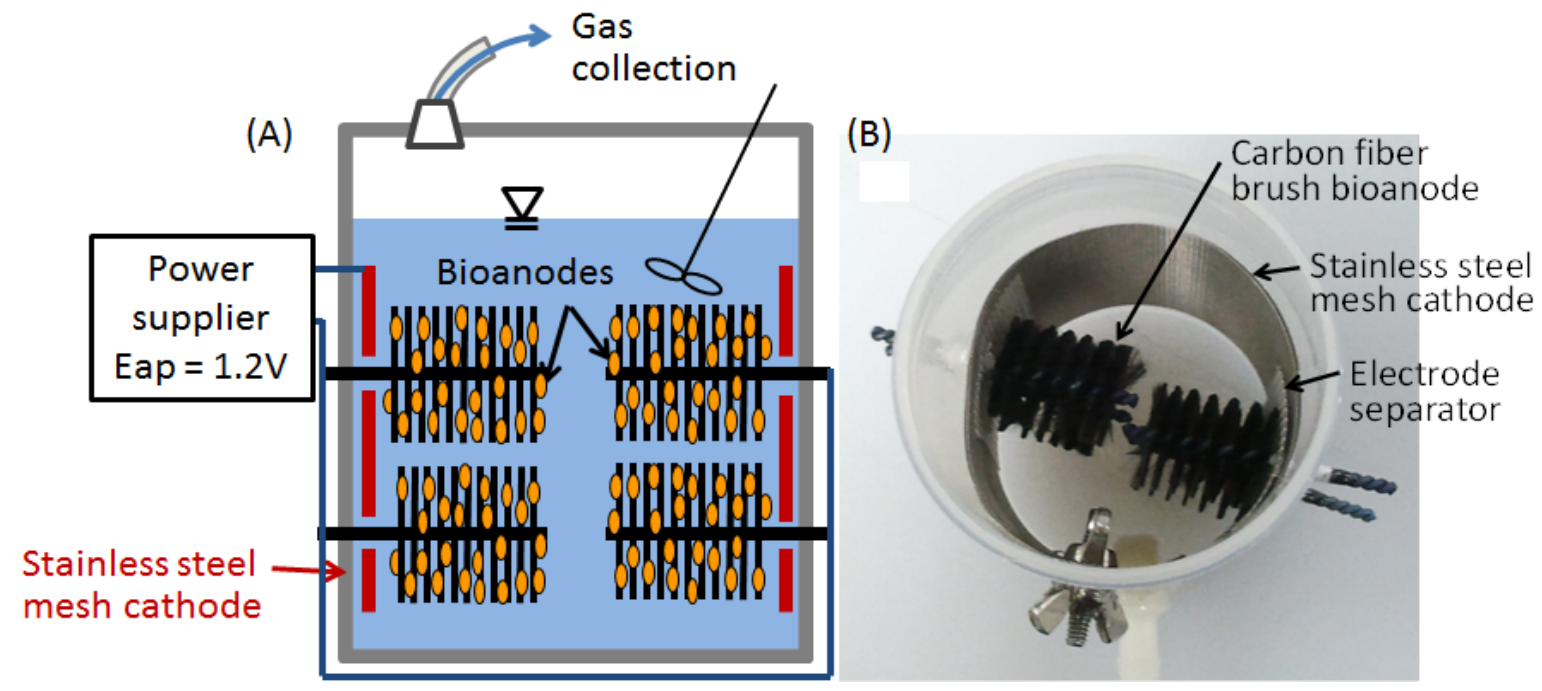

Figure 2. (A) Schematic design of an electrically assisted digester (EAD); and (B) Top view of the constructed EAD. (Continuous mixing provided using magnetic stirrers) 
using two gas chromatography (GC) instruments with a thermal conductivity detector (Varian Star 3400 CX, Agilent Technologies, CA). One GC was equipped with a Porapak-Q packed column (Chromatographic Specialties Inc., Canada) for the separation of $\mathrm{CH}_{4}, \mathrm{CO}_{2}$ and $\mathrm{N}_{2}$ using helium as a carrier gas. The other was used to analyze for $\mathrm{H}_{2}$ and $\mathrm{O}_{2}$ using a Molecular Sieve 5a column with nitrogen as a carrier gas.

\subsection{Efficiency and Recovery Calculations}

Coulombic efficiency $(C E)$ is the electron-based ratio of COD degraded by exoelectrogenic bacteria to the total COD removal $(\triangle \mathrm{COD})$ throughout a fed-batch cycle as previously defined by Logan et al. (2006):

$C E=\frac{8 \int I d t}{F V \triangle C O D}$

where $I$ is the electric current in the EAD; $F$ is the Faraday constant (96485 C/mol); and $V$ is the sludge volume $(240 \mathrm{~mL})$. The electric energy consumed to drive the MEC reactions $\left(W_{E}\right)$ was calculated by integrating the product of the electric potential application $\left(E_{a p}\right)$ and resulting electric current $(I)$ as (Logan et al., 2008):

$W_{E}=\int I E_{a p} d t$

The energy recovered as methane gas $\left(\mathrm{W}_{\mathrm{CH} 4}\right)$ was determined similarly by Logan et al. (2008) as:

$W_{\mathrm{CH} 4}=n_{\mathrm{CH} 4} \Delta H_{\mathrm{CH} 4}$

where $\Delta H_{\mathrm{CH} 4}$ is the heat of combustion of methane (890.8 kJ/ mol) (Haynes, 2013) and $n_{\mathrm{CH} 4}$ is the amount of produced methane in moles. The methane production in moles $\left(n_{\mathrm{CH}}\right)$ was approximated from $\triangle \mathrm{COD}$ as demonstrated in Metcalf and Eddy (2003):

$n_{C H 4}=V \Delta C O D\left(\frac{1 m o l-C H_{4}}{64 g-C O D}\right)$

Equation (4) indicates that the amount of methane production is proportional to the total COD removal in digesters. The conversion factor between mol- $\mathrm{CH}_{4}$ and g-COD was found from oxidation of methane $\left(\mathrm{CH}_{4}+2 \mathrm{O}_{2} \rightarrow \mathrm{CO}_{2}+2 \mathrm{H}_{2} \mathrm{O}\right)$. The energy recovery $\left(r_{E}\right)$ is the ratio between $W_{C H 4}$ and $W_{E}$ as:

$r_{E}=\frac{W_{C H 4}}{W_{E}}$

\subsection{Numerical Model Development}

A steady-state model was developed in order to simulate the rate of biosolids decomposition and microbial growth in the EAD and control digester in accordance with Anaerobic Digestion Model No.1 (ADM1) (Batstone et al., 2002). The developed model includes 21 model components (Table 1) and for each component, a steady-state mass balance equation was built with the kinetic rate expressions described in ADM1 (Table S1). The system of steady-state mass balance equations were solved simultaneously using fixed point iteration (Equations S1 to S21). The numerical model was verified with an example simulation result provided by Rosen and Jeppsson (2006) (Table S2).

The model was further developed to include the MEC reactions in the EAD: acetate destruction at the bioanode (Equation (6)) and $\mathrm{H}_{2}$ gas production at the cathode (Equation (7)) (Logan et al., 2008).

$\mathrm{CH}_{3} \mathrm{COO}^{-}+4 \mathrm{H}_{2} \mathrm{O} \rightarrow 2 \mathrm{HCO}_{3}^{-}+9 \mathrm{H}^{+}+8 e^{-}$

$2 \mathrm{H}^{+}+2 e^{-} \rightarrow \mathrm{H}_{2}$

The rate of these electrode reactions was governed in the model by a fixed electric current density value. For example, $90 \mathrm{~A} / \mathrm{m}^{3}$ is equivalent to $644.74 \mathrm{mg} \mathrm{COD} / \mathrm{L} / \mathrm{d}$ for acetate destruction and $\mathrm{H}_{2}$ gas production. For model simulation, the electric current density was $90 \mathrm{~A} / \mathrm{m}^{3}$, which was the observed average current density during the experiment with SRT of 14 days, unless otherwise noted. The other kinetic parameters used in the mathematical model were taken from the International Water Association (Batstone et al., 2002) and adjusted for $39{ }^{\circ} \mathrm{C}$ (Table 2). In the simulation, the total COD was assumed to be $24000 \mathrm{mg} \mathrm{COD} / \mathrm{L}$ which represents what was found during experimental operation of the EAD and control digesters. This total COD value was approximately fractionated into individual components (Table 1) in accordance with previous model studies on wastewater sludge digestion (Cacho et al., 2002; Parker, 2005; Rosen and Jeppsson, 2006). Note that it is practically impossible to identify all of the individual components in ADM1 simulations.

\section{Results}

\subsection{VSS and COD Removal in EAD and Control Digester}

The MEC reactions expedited biosolids destruction under relatively short SRT conditions. The electrically-assisted digester (EAD) achieved 55\% VSS removal at an SRT of 6 days (Figure 3A). At the same SRT condition, the control digester showed only $47 \%$ VSS removal. When the SRT was sufficiently long at 14 days, the VSS removal was in a narrow range between 61 and 64\% for the EAD and control digester. At a very short SRT condition of 2 days, the VSS removal was also similar (37 39\%) between the EAD and control digester. These results indicate that the MEC reactions enhance the VSS removal only under a certain SRT condition (i.e., 6-day SRT).

The MEC reactions also substantially improved the COD removal at the 6-day SRT. When the SRT was sufficiently 
long at 14 days, the COD removal was consistent at $~ 65 \%$ between the EAD and control digesters (Figure 3B). As the SRT was shortened to 6 days, the control digester showed a substantial drop in COD removal from 66 to 50\%. However, the decrease in the COD removal for the EAD was relatively small from 65 to $61 \%$, implying that the MEC reactions can expedite organic destruction in anaerobic digestion of wastewater treatment sludge. Similar to the VSS removal result, the very short SRT condition (2 days) made the MEC reactions ineffective for additional COD removal in the EAD compared to the control digester.

For the 6-day SRT condition, the VSS destruction rate in the EAD was $0.94 \mathrm{~kg}-\mathrm{VSS} / \mathrm{m}^{3} / \mathrm{d}$, which is $16 \%$ greater than $0.81 \mathrm{~kg}-\mathrm{VSS} / \mathrm{m}^{3} / \mathrm{d}$ in the control digester. The COD destruction rate was also greater in the EAD $\left(1.9 \mathrm{~kg}-\mathrm{COD} / \mathrm{m}^{3} / \mathrm{d}\right)$ by $19 \%$ compared to $1.6 \mathrm{~kg}-\mathrm{COD} / \mathrm{m}^{3} / \mathrm{d}$ found in the control digester. Note that the average VSS and COD loading rates under the 6-day SRT condition were $1.86 \mathrm{~kg}-\mathrm{VSS} / \mathrm{m}^{3} / \mathrm{d}$ and $3.36 \mathrm{~kg}$ $\mathrm{COD} / \mathrm{m}^{3} / \mathrm{d}$, respectively.

\subsection{Electric Current in EAD}

The electric current in the EAD was affected by SRT conditions because the SRT governs the organic loading rate and thus determines the concentration of soluble substrates for exoelectrogenic microorganisms (Figure 4). At an SRT of 2 days, the volume-based current density (specific current) remained high and stable over a continuous fed-batch cycle (between 140 and $190 \mathrm{~A} / \mathrm{m}^{3}$ ) because the relatively high organic loading rate $\left(11.61 \mathrm{~kg} \mathrm{COD} / \mathrm{m}^{3} / \mathrm{d}\right)$ maintained high concentration of soluble substrates for exoelectrogens. The electric current density was similar in magnitude and trend between SR-
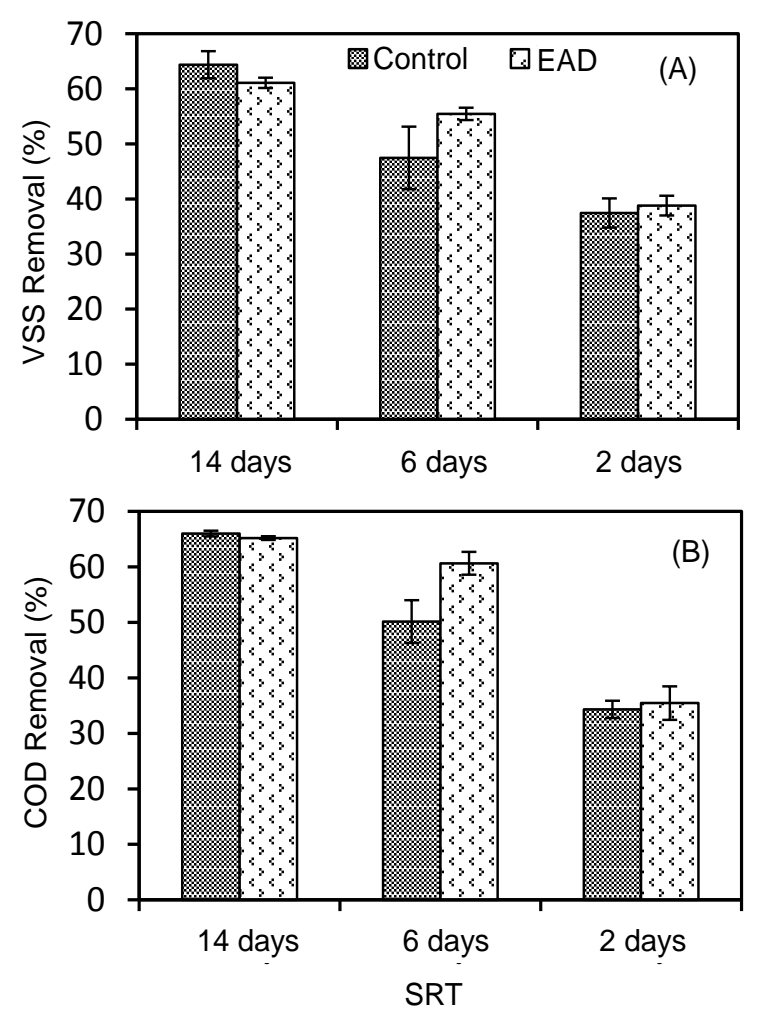

Figure 3. Effects of MEC reactions on (A) VSS removal; and (B) COD removal. The error bar indicates the magnitude of standard deviation $(n=3)$. (Control digester effluent: $\mathrm{pH}=7.5 \pm 0.1$ and conductivity $=3.9 \pm 0.3 \mathrm{mS} / \mathrm{cm}$; EAD effluent: $\mathrm{pH}=7.4 \pm 0.2$ and conductivity $=3.5 \pm 0.3$ $\mathrm{mS} / \mathrm{cm})$

Table 1. Influent Composition of Sludge Used for the Mathematical Model*

\begin{tabular}{lll}
\hline Model component & Symbol & Influent (mg-COD/L) \\
\hline Composites & $\mathrm{X}_{\mathrm{c}}$ & 12000 \\
Particulate Inerts & $\mathrm{X}_{\mathrm{in}}$ & 100 \\
Carbohydrates & $\mathrm{X}_{\mathrm{ch}}$ & 2000 \\
Proteins & $\mathrm{X}_{\mathrm{pr}}$ & 4000 \\
Lipids & $\mathrm{X}_{\mathrm{li}}$ & 2000 \\
Monosaccharide Degraders & $\mathrm{X}_{\mathrm{su}}$ & 100 \\
Amino Acid Degraders & $\mathrm{X}_{\mathrm{aa}}$ & 100 \\
LCFA Degraders & $\mathrm{X}_{\mathrm{fa}}$ & 100 \\
Valerate and Butyrate Degraders & $\mathrm{X}_{\mathrm{c} 4}$ & 100 \\
Propionate Degraders & $\mathrm{X}_{\mathrm{pro}}$ & 100 \\
Acetoclastic Methanogens & $\mathrm{X}_{\mathrm{ac}}$ & 100 \\
Hydrogenotrophic Methanogens & $\mathrm{X}_{\mathrm{h} 2}$ & 100 \\
Monosaccharides & $\mathrm{S}_{\mathrm{su}}$ & 1000 \\
Amino Acids & $\mathrm{S}_{\mathrm{aa}}$ & 1000 \\
Long Chain Fatty Acids & $\mathrm{S}_{\mathrm{fa}}$ & 50 \\
Valerate & $\mathrm{S}_{\mathrm{va}}$ & 50 \\
Butyrate & $\mathrm{S}_{\mathrm{bu}}$ & 50 \\
Propionate & $\mathrm{S}_{\mathrm{pro}}$ & 50 \\
Acetate & $\mathrm{S}_{\mathrm{ac}}$ & 1000 \\
Hydrogen Gas & $\mathrm{S}_{\mathrm{h} 2}$ & 0 \\
Methane Gas & $\mathrm{S}_{\mathrm{ch} 4}$ & 0 \\
\hline
\end{tabular}

"Influent parameters were selected to match the total COD of the influent used in experimentation as well as the typical breakdown found in waste activated sludge. 
Ts of 6 and 14 days (Figure 4). It was high at the beginning of each continuous fed-batch cycle $\left(\sim 150 \mathrm{~A} / \mathrm{m}^{3}\right)$ and it rapidly decreased down to $\sim 50 \mathrm{~A} / \mathrm{m}^{3}$. The current density (specific current) result indicates that acetic acid concentration (or volatile fatty acids) was rapidly consumed in the EAD under 6or 14-day SRT while the acetic acid concentration was maintained high throughout the fed-batch cycle for 2-day SRT. In a separate experiment, an addition of sodium acetate in the EAD was immediately responded with high electric current (data not shown) confirming that current in the EAD is dependent on the concentration of acetic acid. Exoelectrogenic bacteria are known to prefer acetate as a substrate compared to other complex organics even though bioelectrochemical systems have been examined with various types of wastewater (Liu et al., 2005A; Pham et al., 2006; Cheng and Logan, 2007; Chae et al., 2009).
Note that the conductivity of the influent sludge was consistent at $2.2 \pm 0.3 \mathrm{mS} / \mathrm{cm}$ throughout the experiment. The conductivity increased slightly in the EAD digester to $4.1 \pm$ $0.1,3.5 \pm 0.2$, and $2.8 \pm 0.2 \mathrm{mS} / \mathrm{cm}$ for the 14-, 6-, and 2-day SRT conditions, respectively. This gradual increase in the conductivity with the increasing SRT can be explained by the increasing amount of soluble compounds (e.g., organic fatty acids) with time mainly driven by hydrolysis of particulate organics. Even with this increasing effluent conductivity with the increasing SRT, the current density was higher at $140 \sim 190$ $\mathrm{mA} / \mathrm{m}^{3}$ for the 2-day SRT than $40 \sim 160 \mathrm{~mA} / \mathrm{m}^{3}$ under the 6or 14-day SRT (Figure 4), indicating that the low sludge conductivity was not a controlling factor for the electric current generation in the EAD. As discussed in the previous paragraph, the acetate concentration determined the magnitude of the electric current.

Table 2. Model Parameters Used in Mathematical Simulations*

\begin{tabular}{|c|c|c|c|}
\hline Model parameter & Symbol & Value & Unit \\
\hline Max. specific disintegration rate & $\mathrm{k}_{\mathrm{dis}}$ & $5.95 \times 10^{-1}$ & $\mathrm{~d}^{-1}$ \\
\hline Microbial decay rate (all) & $\mathrm{k}_{\mathrm{dec}}$ & $2.38 \times 10^{-2}$ & $\mathrm{~d}^{-1}$ \\
\hline Max. specific hydrolysis rate (all) & khyd & 11.5 & $\mathrm{~d}^{-1}$ \\
\hline Half-saturation value for sugar utilization & $\mathrm{K}_{\mathrm{s}, \mathrm{su}}$ & 595 & $\mathrm{mg}-\mathrm{COD} / \mathrm{L}$ \\
\hline Max. specific sugar utilization rate & $\mathrm{k}_{\mathrm{su}}$ & 54.4 & $\mathrm{~d}^{-1}$ \\
\hline Half-saturation value for amino acid utilization & $\mathrm{K}_{\mathrm{s}, \mathrm{aa}}$ & 300 & $\mathrm{mg}-\mathrm{COD} / \mathrm{L}$ \\
\hline Max. specific amino acid utilization rate & $k_{\text {aa }}$ & 54.4 & $\mathrm{~d}^{-1}$ \\
\hline Half-saturation coefficient for LCFA utilization & $\mathrm{K}_{\mathrm{s}, \mathrm{fa}}$ & 400 & $\mathrm{mg}-\mathrm{COD} / \mathrm{L}$ \\
\hline Max. specific LCAFA utilization rate & $\mathrm{k}_{\mathrm{fa}}$ & 6.82 & $\mathrm{~d}^{-1}$ \\
\hline Half-saturation value for butyrate/valerate utilization & $\mathrm{K}_{\mathrm{s}, \mathrm{c} 4}$ & 238 & $\mathrm{mg}-\mathrm{COD} / \mathrm{L}$ \\
\hline Max. specific butyrate/valerate utilization & $\mathrm{k}_{\mathrm{c} 4}$ & 22.1 & $\mathrm{~d}^{-1}$ \\
\hline Half-saturation value for propionate utilization & $\mathrm{K}_{\mathrm{s}, \text { pro }}$ & 132 & $\mathrm{mg}-\mathrm{COD} / \mathrm{L}$ \\
\hline Max. specific propionate utilization & kpro & 14.5 & $\mathrm{~d}^{-1}$ \\
\hline Half-saturation value for acetoclastic methanogensis & $\mathrm{K}_{\mathrm{s}, \mathrm{ac}}$ & 178 & $\mathrm{mg}-\mathrm{COD} / \mathrm{L}$ \\
\hline Max. specific acetoclastic methanogenesis rate & $\mathrm{k}_{\mathrm{ac}}$ & 9.51 & $\mathrm{~d}^{-1}$ \\
\hline Half-saturation value for hydrogenotrophic methanogenesis & $\mathrm{K}_{\mathrm{s}, \mathrm{h} 2}$ & $1.14 \times 10^{-2}$ & $\mathrm{mg}-\mathrm{COD} / \mathrm{L}$ \\
\hline Max. specific hydrogenotrophic methanogenesis rate & $\mathrm{k}_{\mathrm{h} 2}$ & 35.0 & $\mathrm{~d}^{-1}$ \\
\hline Yield of sugar degraders & $\mathrm{Y}_{\mathrm{su}}$ & $1.00 \times 10^{-1}$ & - \\
\hline Yield of amino acid degraders & $\mathrm{Y}_{\text {aа }}$ & $8.00 \times 10^{-2}$ & - \\
\hline Yield of LCFA degraders & $\mathrm{Y}_{\mathrm{fa}}$ & $6.00 \times 10^{-2}$ & - \\
\hline Yield of butyrate/valerate degraders & $\mathrm{Y}_{\mathrm{c} 4}$ & $6.00 \times 10^{-2}$ & - \\
\hline Yield of propionate degraders & $Y_{\text {pro }}$ & $4.00 \times 10^{-2}$ & - \\
\hline Yield of acetoclastic methanogens & $\mathrm{Y}_{\mathrm{ac}}$ & $5.00 \times 10^{-2}$ & - \\
\hline Yield of hydrogenotrophic methanogens & $\mathrm{Y}_{\mathrm{h} 2}$ & $6.00 \times 10^{-2}$ & - \\
\hline Fraction of inert particulate from composite decomposition & $\mathrm{f}_{\mathrm{i}, \mathrm{xc}}$ & $3.00 \times 10^{-1}$ & - \\
\hline Fraction of carbohydrate from composite decomposition & $\mathrm{f}_{\mathrm{ch}, \mathrm{xc}}$ & $2.00 \times 10^{-1}$ & - \\
\hline Fraction of protein from composite decomposition & $\mathrm{f}_{\mathrm{pr}, \mathrm{xc}}$ & $2.00 \times 10^{-1}$ & - \\
\hline Fraction of lipid from composite decomposition & $\mathrm{f}_{\mathrm{li}, \mathrm{xc}}$ & $3.00 \times 10^{-1}$ & - \\
\hline Fraction of LCFA from lipid decomposition & $\mathrm{f}_{\mathrm{fa}, \mathrm{li}}$ & $9.50 \times 10^{-1}$ & - \\
\hline Fraction of valerate from amino acid decomposition & $\mathrm{f}_{\mathrm{va}, \mathrm{aa}}$ & $2.30 \times 10^{-1}$ & - \\
\hline Fraction of butyrate from sugar decomposition & $\mathrm{f}_{\mathrm{bu}, \mathrm{su}}$ & $1.30 \times 10^{-1}$ & - \\
\hline Fraction of butyrate from amino acid decomposition & $\mathrm{f}_{\mathrm{bu}, \mathrm{aa}}$ & $2.60 \times 10^{-1}$ & - \\
\hline Fraction of propionate from sugar decomposition & $\mathrm{f}_{\text {pro,su }}$ & $2.70 \times 10^{-1}$ & - \\
\hline Fraction of propionate from amino acid decomposition & $f_{\text {pro,aa }}$ & $5.00 \times 10^{-2}$ & - \\
\hline Fraction of acetate from sugar decomposition & $\mathrm{f}_{\mathrm{ac}, \mathrm{su}}$ & $4.10 \times 10^{-1}$ & - \\
\hline Faction of acetate from amino acid decomposition & $\mathrm{f}_{\mathrm{ac}, \text { aa }}$ & $4.00 \times 10^{-1}$ & - \\
\hline Fraction of $\mathrm{H}_{2}$ gas from sugar decomposition & $\mathrm{f}_{\mathrm{h} 2, \mathrm{su}}$ & $1.90 \times 10^{-1}$ & - \\
\hline Fraction of $\mathrm{H}_{2}$ gas from sugar decomposition & $\mathrm{f}_{\mathrm{h} 2 \text {,aa }}$ & $6.00 \times 10^{-2}$ & - \\
\hline
\end{tabular}

"Parameters were taken from Batstone et al. (2002) and adjusted for $39^{\circ} \mathrm{C}$ and $\mathrm{pH} 7$. 


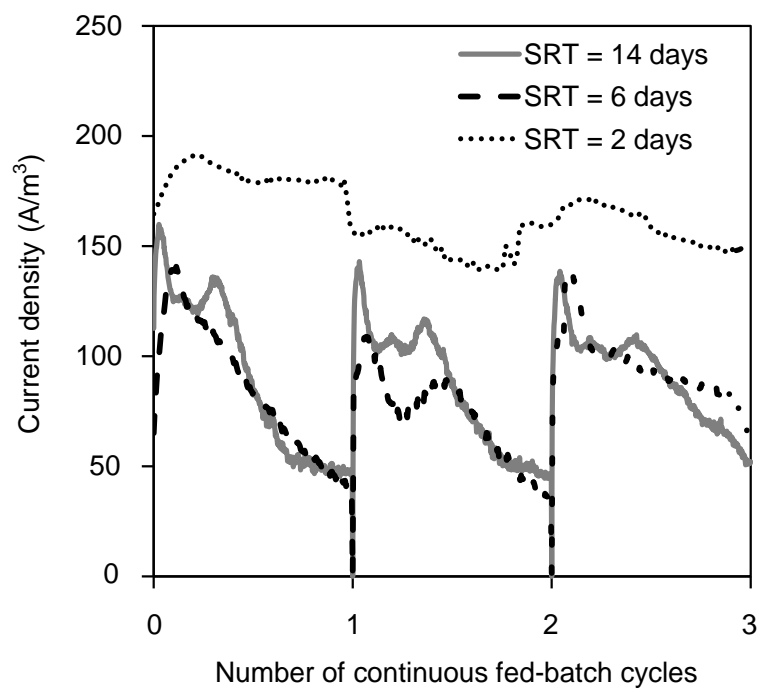

Figure 4. Effect of SRT on electric current generation in the EAD. The $x$-axis (number of continuous fed-batch cycles) was prepared by normalizing time by the length of fed batch cycle; thus, one cycle unit is 7 days (14-day SRT), 3 days (6day SRT) and 1 day (2-day SRT). (Electric current density (specific current) obtained by normalizing electric current by the sludge volume in the EAD, $240 \mathrm{~mL}$ )

\subsection{Coulombic Efficiency and Energy Recovery}

The Coulombic efficiency (CE) in the EAD was relatively high at $30 \%$ for the 14-day SRT (Figure 5), indicating that $30 \%$ of the removed COD was contributed by the MEC reactions. At the 6-day SRT condition, the $C E$ was substantially reduced down to $16 \%$ and this reduced $C E$ can be explained by the shortened time for the MEC reactions (from 7- to 3day continuous fed-batch cycle) which increased the organic loading rate from $1.53 \mathrm{~kg} \mathrm{COD} / \mathrm{m}^{3} / \mathrm{d}$ (14-day SRT) to $3.36 \mathrm{~kg}$ $\mathrm{COD} / \mathrm{m}^{3} / \mathrm{d}$ (6-day SRT). Since the magnitude of electric current density was similar for both the 6- and 14-day SRT conditions, the bioanode of the EAD oxidized acetate at a similar rate. Since the organic loading rate was roughly doubled, the $C E$ dropped by roughly one half. However, when the SRT was further decreased from 6 to 2 days, the $C E$ was maintained at $14 \%$ (Figure 5) because the electric current was substantially boosted (Figure 4) and the COD removal drop from 61 to $35 \%$ (Figure 3 ). The energy recovery $\left(r_{E}\right)$ was high above $300 \%$ under the 6- and 2-day SRT conditions while it was relative low at $\sim 160 \%$ at the 14-day SRT condition (Figure 5).

\subsection{Gas Composition}

$\mathrm{H}_{2}$ gas was not detected in the GC analysis and the biogas consisted mainly of $\mathrm{CH}_{4}(50 \sim 60 \%)$ and $\mathrm{CO}_{2}$ (40 50\%) both in the EAD and control digester. In addition, the biogas fractions were not affected by the SRT condition. Unlike the very high $\mathrm{CH}_{4}$ fraction (98.1\%) reported in a recent study (Bo et al., 2014), the $\mathrm{CH}_{4}$ content in the biogas was not affected by the MEC reactions as the gas composition was almost identical between the EAD and control digester. This result imp- lies that the MEC reactions do not change the resulting ratio between $\mathrm{CH}_{4}$ and $\mathrm{CO}_{2}$ even though they not only altered the reaction pathways (Figure 1) but also accelerated the overall rate of biosolids destruction (Figure 3). This inconsistent $\mathrm{CH}_{4}$ fraction result with the previous study needs further investigation in future study (Bo et al., 2014). Note that the MEC reactions were considered to increase the $\mathrm{CH}_{4}$ content and decrease the $\mathrm{CO}_{2}$ fraction because the cathode reaction produces $\mathrm{H}_{2}$ gas and hydrogenotrophic methanogenesis $\left(4 \mathrm{H}_{2}+\mathrm{CO}_{2} \rightarrow\right.$ $\mathrm{CH}_{4}+2 \mathrm{H}_{2} \mathrm{O}$ ) consumes $\mathrm{CO}_{2}$ (Bo et al., 2014).

\subsection{Model Simulation Results}

In the numerical model simulation, the EAD removed more total COD than the control digester for SRTs below 8 days (Figure 6A). At an SRT of 5 or 6 days, the EAD showed the greatest improvement with $12 \%$ more COD removal compared to the control digester. Due to the additional acetate removal by the MEC bioanode, the acetoclastic methanogen population $\left(\mathrm{X}_{\mathrm{ac}}\right)$ in the EAD was consistently lower than that in the control digester for the SRT of 7 days or longer (Figure $6 \mathrm{~B})$. Even with the lower acetoclastic methanogen population, the effluent acetate concentration $\left(\mathrm{S}_{\mathrm{ac}}\right)$ was distinctively lower in the EAD than that in the control digester (Figure 6C), indicating that the bioanode successfully replaces the role of acetoclastic methanogens in biosolids destruction. Note that the rapid increase in acetate concentration for 3 days $\left(\mathrm{S}_{\mathrm{ac}}\right)$ can be explained by active fermentation of sugars $\left(\mathrm{S}_{\mathrm{su}}\right)$ and amino acids $\left(\mathrm{S}_{\mathrm{aa}}\right)$. The concentration of hydrogenotrophic methanogens $\left(\mathrm{X}_{\mathrm{h} 2}\right)$ on the other hand was consistently higher in the E$\mathrm{AD}$ due to the enhanced $\mathrm{H}_{2}$ gas production at the MEC cathode. In both digesters, $\mathrm{H}_{2}$ gas $\left(\mathrm{S}_{\mathrm{h} 2}\right)$ was rapidly consumed by hydrogenotrophic methanogens, resulting in very low $\mathrm{H}_{2}$ gas concentration below $0.005 \mathrm{mg}-\mathrm{COD} / \mathrm{L}$ for all of the examined SRT conditions (Figure 6C). When the SRT was very short (< 3 days), the fermenting and beta-oxidizing microorganisms

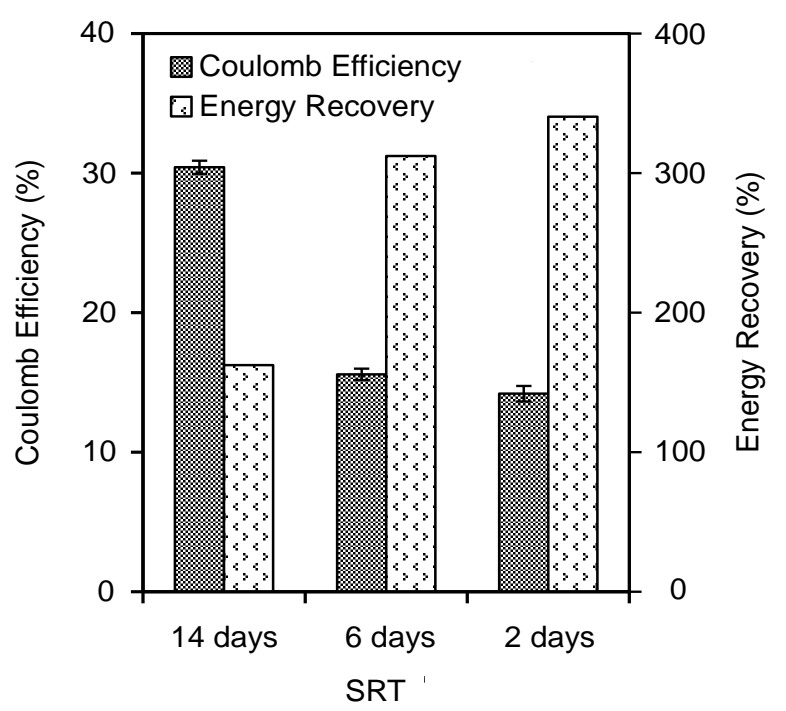

Figure 5. Coulombic efficiency ( $C E)$ and energy recovery $\left(r_{E}\right)$ in EAD operation. 
$\left(\mathrm{X}_{\mathrm{su}}, \mathrm{X}_{\mathrm{aa}}\right.$ and $\mathrm{X}_{\mathrm{fa}}$ ) were not sufficiently enriched.

Note that the model simulation results are provided to support our main hypothesis: the MEC reactions supplement the rate-limiting acetoclastic methanogenesis reaction and thus enhance the rate of biosolids destruction in anaerobic digestion. Due to difficulties in analyzing the individual solids components $\left(\mathrm{X}_{\mathrm{c}}, \mathrm{X}_{\mathrm{in}}, \mathrm{X}_{\mathrm{li}}, \mathrm{X}_{\mathrm{ch}}, \mathrm{X}_{\mathrm{pr}}, \mathrm{X}_{\mathrm{c} 4}, \mathrm{X}_{\mathrm{fa}}, \mathrm{X}_{\mathrm{aa}}, \mathrm{X}_{\mathrm{su}}, \mathrm{X}_{\mathrm{pro}}, \mathrm{X}_{\mathrm{ac}}\right.$, and $\mathrm{X}_{\mathrm{h} 2}$ ) in the sludge used in the experiment, precise comparison between experimental results and model simulations was not conducted in this study. However, it should be emphasized that the total COD removal is consistent between the experimental results (Figure 3B) and model simulations (Figure 6A) within a reasonable range.

\section{Discussion}

\subsection{Insignificant Contribution by MEC at 14- or 2-day S- RT}

In this study, the MEC reactions (acetate oxidation and $\mathrm{H}_{2}$ gas production) were implemented to partially replace acetoclastic methanogenesis. Since hydrogenotrophic methanogenesis is sufficiently rapid in converting $\mathrm{H}_{2}$ gas into $\mathrm{CH}_{4}$, the MEC reactions coupled with hydrogenotrophic methanogenesis can be considered to play the same role of acetoclastic methanogenesis (i.e., conversion of acetic acid into $\mathrm{CH}_{4}$ ). At the 14-day SRT condition, the $C E$ of $30 \%$ indicates that the MEC reactions contributed $30 \%$ of the total COD removal in the EAD, replacing a significant fraction of acetoclastic methanogenesis. Even with this substantial contribution, the EAD did not show noticeable improvements in the VSS and COD removal compared to the control digester (Figure 3). This experimental observation is consistent with the negligible improvement in the COD removal in the model simulation results under long SRT conditions (SRT > $8 \mathrm{~d}$ ) (Figure 6A). This negligible improvement can be explained by the fully enriched acetoclastic methanogen population $\left(\mathrm{X}_{\mathrm{ac}}\right)$ in the control reactor (Figure 6B). Thus, the bioanode competes with acetoclastic methanogens for a limited amount of acetate (Figure 6C) rather than supplementing acetoclastic methanogenesis; as a result, the additional acetate removal by the bioanode in the EAD did not improve the overall COD and VSS removal compared to the control digester.

Under a 2-day SRT condition, the rate of biosolids destruction was limited by multiple reactions, including hydrolysis, beta-oxidation and acetoclastic methanogenesis. Hydrolysis is driven by extracellular enzymes produced by both fermentative and beta-oxidizing microorganisms (Grady et al., 2011; Halalsheh et al., 2011; Kim et al., 2012; Meng et al.,
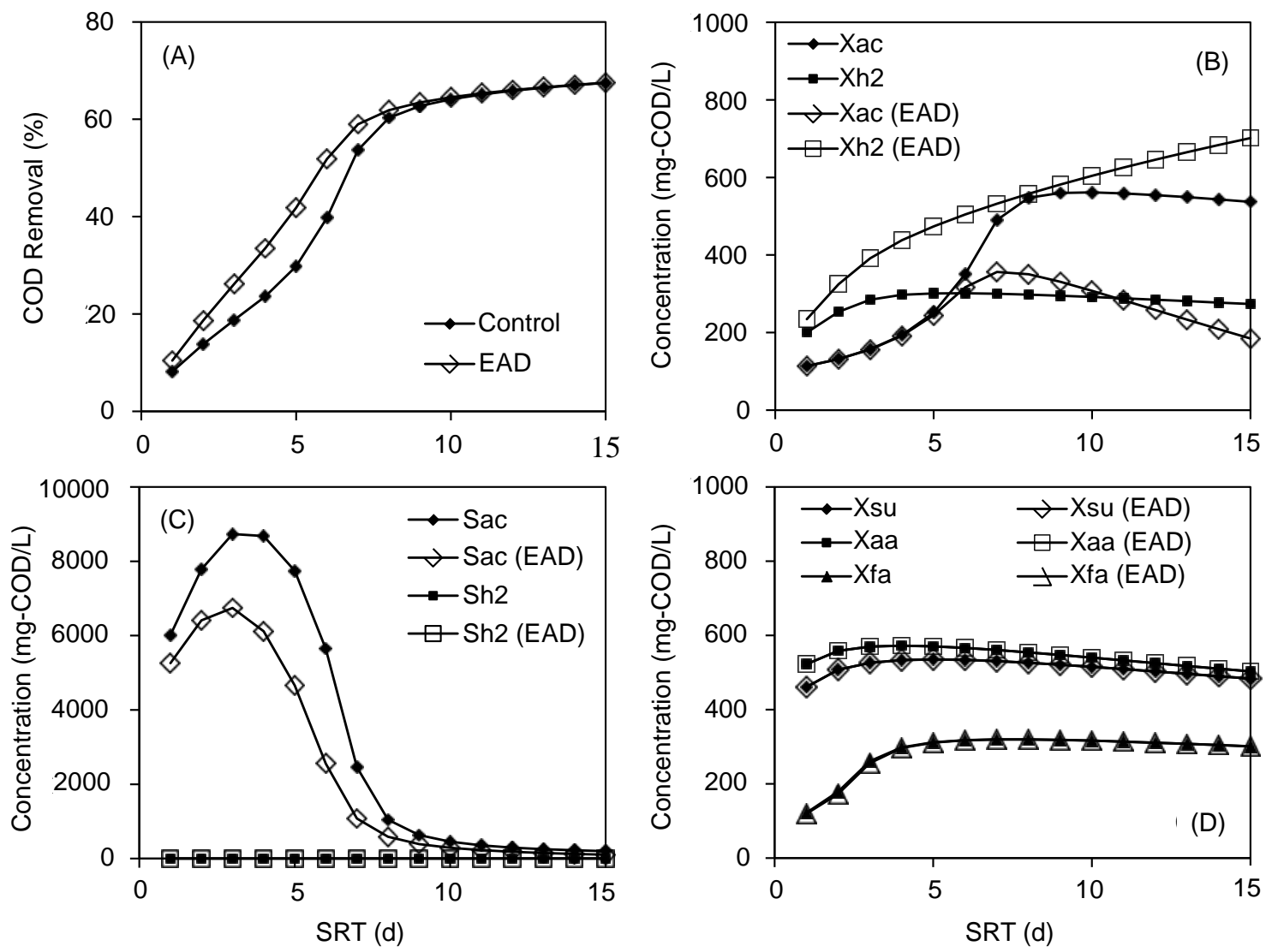

Figure 6. Mathematical simulation results for (A) Total COD Removal; (B) Methanogen population; (C) Acetate and $\mathrm{H}_{2}$ gas; (D) acidogenic bacteria population. Electric current density was fixed at $90 \mathrm{~A} / \mathrm{m}^{3}$ for the EAD. The influent composition is given in Table 1 and the kinetic constants are listed in Table 2. 
2015). Among these microorganisms, beta-oxidizing bacteria $\left(\mathrm{X}_{\mathrm{fa}}\right)$ are not fully enriched at the very short 2-day SRT condition (Figure 6D), making hydrolysis one of the rate-limiting reactions. Since the overall reaction is bottlenecked by hydrolysis and beta-oxidation, the addition of the MEC reactions in the EAD did not bring meaningful improvement in COD and VSS removal compared to the control reactor (Figures 3 and 6A).

\subsection{MEC Contribution to Expedited Biosolids Destruction at 6-day SRT}

MEC reactions substantially expedited biosolids destruction with the 55\% VSS removal and 61\% COD removal in 6 days in the EAD (Figure 3). This result indicates that the MEC reactions (i.e., acetate oxidation at the bioanode and $\mathrm{H}_{2}$ production at the cathode) successfully supplemented the role of acetoclastic methanogens, which is substantially limited at the 6-day SRT condition. Produced $\mathrm{H}_{2}$ gas at the MEC cathode was rapidly converted into $\mathrm{CH}_{4}$ by hydrogenotrophic methanogens as $\mathrm{H}_{2}$ was not detected in the gas chromatography analysis. The observed CE during the 6-day SRT operation (Figure 5) indicates that $16 \%$ of the removed COD went through the MEC reactions. Thus, the MEC reactions are responsible for $\sim 10 \%$ of the total COD removal in the EAD (product of $C E=16 \%$ and COD removal $=61 \%$ ). This $10 \%$ contribution is consistent with the difference in the COD removal between $61 \%$ in the $\mathrm{EAD}$ and $50 \%$ in the control digester.

The mathematical model results are also consistent with the experimental observation as the EAD outperforms the control digester only for the SRTs around 6 days (Figure 6A). In the EAD, the acetate concentration was significantly lower than that in the control digester (Figure 6C), indicating that the bioanode reaction successfully supplemented the slow acetoclastic methanogenesis reaction (Figure 1). While we did not analyze the experimental samples for acetate concentration, we observed consistently lower acetate concentration in the EAD by $30 \sim 40 \%$ compared to that in the control digester in another set of experiments (Asztalos and Kim, 2015).

The improved VSS removal can be indirectly attributed to the reduced acetate concentration $\left(\mathrm{S}_{\mathrm{ac}}\right)$ in the EAD (Figure $6 C)$. The reduced acetate concentration makes the fermentation reaction more thermodynamically spontaneous, providing a more favorable environment for fermentative microorganisms to grow (McCarty, 1975). Since hydrolysis is driven by enzymes excreted by these microorganisms, the rate of VSS removal is consequently enhanced. This indirect enhancement to hydrolysis requires further attention in future studies and should be implemented in future mathematical models as the current ADM1 employs a simplified kinetic equation for the hydrolysis step (Grady et al., 2011).

\subsection{Acetoclastic Methanogenesis at 6-day SRT}

During the digester operation at the 6-day SRT, acetoclastic methanogenesis made a relatively small contribution to biosolids destruction compared to a 14-day SRT operation. There are only two known microbial genera for acetoclastic methanogens: Methanosarcina and Methanosaeta. Methanosarcina requires an SRT of at least $3 \sim 5$ days for enrichment while Methanosaeta species are even slower, requiring a minimum of 12 days to initiate active methanogenesis from acetate oxidation (Grady et al., 2011). While Methanosaeta species are slow growers they are known to utilize acetate more effectively than Methanosarcina. For instance, the half saturation constant was found to be $90 \mathrm{mg} \mathrm{COD} / \mathrm{L}$ for Methanosaeta and $320 \mathrm{mg}$ COD/L for Methanosarcina (Conklin et al., 2006). This trend in the half saturation coefficient was confirmed in a review article with of $0.1 \sim 1.2 \mathrm{mM}$ (acetate) for $\mathrm{Me}$ thanosaeta and $3.0 \sim 4.5 \mathrm{mM}$ for Methanosarcina (Aiyuk et al., 2006). The greater half saturation coefficient values indicate that Methanosarcina cannot actively utilize acetate at a low concentration, making Methanosarcina species less responsible for acetoclastic methanogenesis than Methanosaeta in anaerobic digesters (Liu and Whiteman, 2008). In our experiments at the 6-day SRT, it is thought that Methanosarcina was present while most of the Methanosaeta was washed out from the digesters because of their slow enrichment $(>12$ days). Therefore, acetoclastic methanogenesis driven only by Methanosarcina made a relatively minor contribution to the overall biosolids destruction. Because of this limited contribution by acetoclastic methanogenesis, the biosolids destruction in the control digester dropped substantially from 64 to $47 \%$ in the VSS removal when the SRT was decreased from 14 to 6 days (Figure 3A). While Methanosaeta and Methanosarcina species are not separately reflected in ADM1, the simulation result showed a consistent trend with the experimental observation as the population of acetoclastic methanogens ( $\mathrm{X}_{\mathrm{ac}}$ in Figure 6B) was not sufficiently high under the 6-day SRT condition, leaving the large amount of residual acetate in the control digester ( $\mathrm{S}_{\mathrm{ac}}$ in Figure 6C).

Even though acetate concentration was not measured in this study, it is evident that the MEC bioanode dominantly consumes acetate (Liu et al., 2005a; Logan et al., 2006; Logan et al., 2008). As a result, low acetate concentration was consistently reported in anaerobic digestion systems coupled with the MEC reactions (Liu et al., 2012; Guo et al., 2013; Choi and Ahn, 2014; Wang et al., 2014; Asztalos and Kim, 2015). These literature articles strongly indicate that the presence of the MEC reactions reduces acetate concentration and thus leads to supplementing the rate-limiting acetoclastic methanogenesis reaction.

\subsection{Sufficiently Rapid Hydrogenotrophic Methanogenesis}

It should be emphasized that $\mathrm{H}_{2}$ gas was not detected in the GC analysis throughout the experiments. This GC analysis result is consistent with the simulation result as the $\mathrm{H}_{2}$ concentration $\left(\mathrm{S}_{\mathrm{h} 2}\right)$ was always very low, below $5 \times 10^{-3} \mathrm{mg}-\mathrm{COD}$ /L (Figure 6C). In addition, the $\mathrm{H}_{2}$ concentration in the EAD was higher than that in the control digester by a subtle difference $\left(<7.5 \times 10^{-3} \mathrm{mg}-\mathrm{COD} / \mathrm{L}\right)$. This absence of $\mathrm{H}_{2}$ in the collected biogas indicates that hydrogenotrophic methanogen- 
esis was sufficiently rapid compared to the rate of $\mathrm{H}_{2}$ gas production by the MEC cathode reaction, beta-oxidation (anaerobic oxidation) and fermentation. Hydrogenotrophic methanogens was sufficiently enriched in 3 days (Figure 6B). In addition to their rapid growth, the rate of their metabolic consumption of $\mathrm{H}_{2}$ gas was found to be very fast. The depth of liquid sludge in the built digester was $7 \mathrm{~cm}$ and the MEC cathode was placed vertically around the inner wall of the digester. Thus, the average travel distance of $\mathrm{H}_{2}$ bubbles produced at the cathode is $3.5 \mathrm{~cm}$ before they reach the gas-and-liquid interface. Therefore, the absence of $\mathrm{H}_{2}$ gas means that hydrogenotrophic methanogenesis was sufficiently fast to achieve complete consumption of $\mathrm{H}_{2}$ gas while the gas bubbles travel the short distance $(3.5 \mathrm{~cm})$.

\subsection{Estimation of Acetic Acid Concentration using Elec- tric Current in EAD}

The magnitude of electric current in the EAD directly indicates the activity of exoelectrogenic bacteria which utilize volatile fatty acids (mainly acetic acid) as a substrate (Liu et al., 2005A; Cheng and Logan, 2007; Chae et al., 2009). As such, the trends in volume-based current density (specific current) throughout a cycle describe the change in volatile fatty acids concentration in the EAD. At the 2-day SRT condition, the consistently high current density (140 $190 \mathrm{~A} / \mathrm{m}^{3}$, Figure 4 ) indicates that a relatively high concentration of acetic acid was maintained throughout the continuous fed-batch cycle. The trends in the electric current were very similar between the 14- and 6-day SRT conditions. This similarity indicates that the acetic acid concentration under the 6-day SRT was as low as that under the 14-day SRT, proving that the MEC reactions successfully replaced acetoclastic methanogenesis and kept the acetate concentration low. As a result, the COD removal was relatively unaffected (from 65 to $61 \%$ ) in the EAD with the decreasing SRT from 14 to 6 days while the COD removal substantially dropped from 66 to $50 \%$ in the control digester.

\subsection{Potential Retention of Slowly Growing Microorganis- ms near Bioanodes}

When the EAD and control digester was autopsied after 4 months of experimental operation, very thick biofilms (about the diameter of the graphite fiber brush of $2 \mathrm{~cm}$ ) were formed on the brush anode in the EAD. A recent study performed concluded that such anode biofilms increase the retention of slowly growing microorganisms (e.g., acetoclastic methanogens) in the EAD and thus enhance the rate of anaerobic digestion (De Vrieze et al., 2014). However, in our study, such thick biofilms were not observed on the graphite brushes in the control digester, indicating that solid retention near the graphite brush did not play an important role in enhancing the rate of anaerobic digestion in this study. This inconsistent result with the previous study (De Vrieze et al., 2014) can be explained by the use of a different type of anode materials that cannot hold biomass long enough without electric current.

\section{Conclusions}

The electrically-assisted digester (EAD) demonstrated promising results by removing 55\% VSS and $61 \%$ of total COD under a 6-day SRT. These results were achieved by the implementation of MEC reactions in which exoelectrogenic bacteria supplemented acetic acid uptake as acetoclastic methanogens were limited under this relatively short SRT. The EAD provided enhanced performance compared to the control digester under a 6-day SRT. When the SRT was 14 days, acetoclastic methanogens in the digesters were enriched enough such that the contribution by MEC reactions in the EAD $(30 \%$ of total COD removal) did not improve the overall VSS and COD removal compared to the control digester. At the 2-day SRT condition, anaerobic reactions other than acetoclastic methanogenesis (e.g., hydrolysis and beta-oxidation) limit the overall rate of biosolids digestion, preventing the additional acetic acid removal by the MEC reactions from accelerating the overall biosolids destruction. Based on our lab-scale experiment results, the EAD was shown to effectively accelerate wastewater sludge digestion for SRT conditions near 6 days. The rate of hydrogenotrophic methanogenesis was found to be sufficiently rapid in the EAD. As a result, $\mathrm{H}_{2}$ gas was not detected in the collected biogas even with the additional $\mathrm{H}_{2}$ gas production from the cathode. The energy recovery $\left(r_{E}\right)$ as methane gas was more than three times the electric energy consumed to drive the MEC electrode reaction. This finding indicates that the energy requirement in the EAD is not high, showing promising potentials for practical applications in wastewater treatment facilities.

A mathematical model was also built by modifying ADM1. The simulation results showed that the MEC reactions successfully decrease acetic acid concentration. This finding supports our hypothesis: the MEC reactions supplement the rate-limiting acetoclastic methanogenesis reaction. Also, the simulation results showed improved COD removal in the EAD only for relatively short SRT conditions ( $<8$ days).

The results demonstrated that the MEC reactions can be integrated into conventional mesophilic anaerobic digesters at a lab-scale to enhance the destruction of VSS and COD. Further work is required to determine whether this system can be properly up-scaled from a $250-\mathrm{mL}$ reactor and if the EAD can be used with various grades of influents (e.g., thickened wastewater sludge or high-strength agricultural wastewater). This study showed relatively limited experimental information as individual fatty acid concentration, including acetic acid, was not provided. Thus, the suggested mechanism on how the MEC reactions improve biosolids destruction needs to be further investigated in future study.

\section{Symbols and Units}

The symbols in Anaerobic Digestion Model No.1 are defined in Tables 1 and 2.

ADM1 Anaerobic Digestion Model No.1

CE Coulombic efficiency (-) 


$\begin{array}{ll}\text { COD } & \text { Chemical oxygen demand (mg/L) } \\ \text { EAD } & \text { Electrically assisted digester } \\ \text { Eap } & \text { Applied voltage (V) } \\ F & \text { Faraday constant (96485 C/mol) } \\ \text { GC } & \text { gas chromatography } \\ I & \text { Electric current (A) } \\ \text { MEC } & \text { Microbial electrolysis cell } \\ n_{C H 4} & \text { Amount of methane (mol) } \\ r_{E} & \text { Energy recovery (-) } \\ \text { SRT } & \text { Solids retention time (d) } \\ V & \text { Reactor volume (0.24 L) } \\ \text { VSS } & \text { Volatile suspended solids (mg/L) } \\ W_{C H 4} & \text { Energy recovered as methane gas }(\mathrm{J}) \\ W_{E} & \text { Electric energy provided }(\mathrm{J}) \\ \Delta H_{C H 4} & \text { Heat of combustion of methane }(890.8 \mathrm{~kJ} / \mathrm{mol})\end{array}$

Acknowledgements. This study was supported by New Faculty Start-up Fund (Department of Civil Engineering, McMaster University) and Discovery Grants (RGPIN/435547-2013, Natural Sciences and Engineering Research Council of Canada). The authors thank Ms. Anna Robertson and Mr. Peter Koudys for their help on equipment operation and reactor construction. The authors also thank the City of Hamilton for providing wastewater treatment sludge.

Supporting Material. The supporting material containing Table S1, Equations S1 to S21, and Table S2 are available at http://www.iseis. org/jei/download/Supplement_15JM012816I.pdf.

\section{References}

Aiyuk, S., Forrez, I., Lieven, D.K., van Haandel, A., and Verstraete, W. (2006). Anaerobic and complementary treatment of domestic sewage in regions with hot climates - A review. Bioresour Technol., 97(17), 2225-2241. http://dx.doi.org/10.1016/j.biortech.2005.05.01 5

Asztalos, J.R., and Kim, Y. (2015). Psychrophilic digestion of waste activated sludge using microbial electrolysis cells. Water Res., under review.

Batstone, D.J., Keller, J., Angelidaki, I., Kalyuzhnyi, S.V., Pavlostathis, S.G., Rozzi, A., Sanders, W.T.M, Siegrist, H., and Vavilin, V.A. (2002). Anaerobic Digestion Model No.1 (ADM1), IWA Publishing, London, UK.

Bo, T., Zhu, X., Zhang, L., Tao, Y., He, X., Li, D., and Yan, Z. (2014). A new upgraded biogas production process: Coupling microbial electrolysis cell and anaerobic digestion in single-chamber, barrelshape stainless steel reactor. Electrochem. Commun., 45, 67-70. http://dx.doi.org/10.1016/j.elecom.2014.05.026

Cacho Rivero, J.A., Suidan, M.T., Ginestet, P., and Audic, J.M. (20 02). Effect of SRT on the anaerobic digestion of excess municipal sludge, Proc. of WEFTEC 2002, Chicago, IL.

Call, D., and Logan, B.E. (2008). Hydrogen production in a single chamber microbial electrolysis cell lacking a membrane. Environ. Sci. Technol., 42(9), 3401-3406. http://dx.doi.org/10.1021/es80018 22

Chae, K.J., Choi, M.J., Lee, J.W., Kim, K.Y., and Kim, I.S. (2009). Effect of different substrates on the performance, bacterial diver- sity, and bacterial viability in microbial fuel cell. Bioresour. Technol., 100(14), 3518-3525. http://dx.doi.org/10.1016/j.biortech.2009. 02.065

Cheng, S., and Logan, B.E. (2007). Sustainable and efficient biohydrogen production via electrohydrogenesis. Proc. Natl. Acad. Sci. U.S.A., 104(47), 18871-18873. http://dx.doi.org/10.1073/pnas.070 6379104

Choi, J., and Ahn, Y. (2014). Increased power generation from primary sludge in microbial fuel cells coupled with prefermentation. Bioprocess Biosystems Eng., 37(12), 2549-2557. http://dx.doi.org/ 10.1007/s00449-014-1232-3

Conklin, A., Stensel, H.D., and Ferguson, J. (2006). Growth kinetics and competition between Methanosarcina and Methanosaeta in mesophilic anaerobic digestions. Water Environ. Res., 78(5), 486496.

De Vrieze, J., Gildemyn, S., Arends, J.B.A., Vanwonterghem, I., Verbeken, K., Boon, N., Verstraete. W., Tyson, G.W., Hennebel, T., and Rabaey, K. (2014). Biomass retention on electrodes rather than electrical current enhances stability in anaerobic digestion. Water Res., 54, 211-221. http://dx.doi.org/10.1016/j.watres.2014.01.044

Eaton, A.D., Clesceri, L.S., Rice, E.W., and Greenberg, A.E. (2005). Standard Methods for Examination of Water and Wastewater, 21st Ed., APHA (American Public Health Association).

Ge, Z., Zhang, F., Grimaud, J., Hurst, J., and He, Z. (2013). Longterm investigation of microbial fuel cells treating primary sludge or digested sludge. Bioresour. Technol., 136, 509-514. http://dx.doi. org/10.1016/j.biortech.2013.03.016

Grady, L.C., Daigger, G.T., Love, N.G., and Filipe, C.D. (2011). Biological Wastewater Treatment, 3rd Ed., Taylor and Francis Group.

Guo, X., Liu, J., and Xiao, B. (2013). Bioelectrochemical enhancement of hydrogen and methane production from the anaerobic digestion of sewage sludge in single-chamber membrane-free microbial electrolysis cells. Int. J. Hydrogen Energy, 38(3), 1342-1347. http://dx.doi.org/10.1016/j.ijhydene.2012.11.087

Halalsheh, M., Kassab, G., Yazajeen, H., Qumsieh, S., and Field, J. (2 011). Effect of increasing the surface area of primary sludge on anaerobic digestion at low temperature. Bioresour. Technol., 102(2), 748-752. http://dx.doi.org/10.1016/j.biortech.2010.08.075

Hao, R. X., Li, S. M., Li, J. B., Zhang, Q. K., \& Liu, F. (2013). Water quality assessment for wastewater reclamation using principal component analysis. J. Environ. Inform., 21(1), 45-54. doi:10.3808 /jei.201300231

Haynes, W.M. (2013). CRC Handbook of Chemistry and Physics, 94 th Ed., CRC Press.

Hu, H., Fan, Y., and Liu, H. (2008). Hydrogen production using single-chamber membrane-free microbial electrolysis cells. Water Res., 42(15), 4172-4178. http://dx.doi.org/10.1016/j.watres.2008.0 6.015

Kim, H.W., Nam, J.Y., Kang, S.T., Kim, D.H., Jung, K.W., and Shin, H.S. (2012). Hydrolytic activities of extracellular enzymes in thermophilic and mesophilic anaerobic sequencing-batch reactions treating organic fractions of municipal solid wastes. Bioresour. Technol., 110, 130-134. http://dx.doi.org/10.1016/j.biortech.2012.0 1.146

Liu, H., Cheng, S., and Logan, B.E. (2005). Production of electricity from acetate or butyrate using a sing-chamber microbial fuel cell. Environ. Sci. Technol., 39(2), 658-662. http://dx.doi.org/10.1021/e s048927c

Liu, H., Grot, S., and Logan, B.E. (2005). Electrochemically assisted microbial production of hydrogen from acetate. Environ. Sci. Technol., 39(11), 4317-4320. http://dx.doi.org/10.1021/es050244p

Liu, W., Cai, W., and Wang, A. (2013). Enhanced methane generation from waste activated sludge in a bioelectrochemical assisted anaerobic reactor, Proc. of the fourth International Microbial Fuel Cell 
Conference, Caims, Australia.

Liu, W., Huang, S., Zhou, A., Zhou, G., Ren, N., Wang, A., and Zhuang, G. (2012). Hydrogen generation in microbial electrolysis cell feeding with fermentation liquid of waste activated sludge. Int. J. Hydrogen Energy, 37(18), 13859-13864. http://dx.doi.org/10.10 16/j.ijhydene.2012.04.090

Liu, Y., and Whiteman, W.B. (2008). Metabolic, phylogenetic, and ecological diversity of the methanogenic archaea. Ann. N. Y. Acad. Sci., 1125, 171-189. http://dx.doi.org/10.1196/annals.1419.019

Logan, B.E., Call, D., Cheng, S., Hamelers, H.V.M., Sleutels, T.H. J.A., Jeremiasse, A.W., and Rozendal, R.A. (2008). Microbial electrolysis cells for high yield hydrogen gas production from organic matter. Environ. Sci. Technol., 42(23), 8360-8640. http://dx.doi. org/10.1021/es801553z

Logan, B.E., Hamerlers, B., Rozendal, R., Schroder, U., Keller, J., Frequia, S., Aelterman, P., Verstraete, W., and Rabaey, K. (2006). Microbial fuel cells: Methodology and terminology. Environ. Sci. Technol., 40(17), 5181-5192. http://dx.doi.org/10.1021/es0605016

Lu, L., Xing, D., Liu, B., and Ren, N. (2012). Enhanced hydrogen production from waste activated sludge by cascade utilization of organic matter in microbial electrolysis cells. Water Res., 46(4), 1015-1026. http://dx.doi.org/10.1016/j.watres.2011.11.073

McCarty, P.L. (1975). Stoichiometry of biological reactions. Prog. Water Technol., 7(1), 157-172.

Meng, Y., Li, S., Yuan, H., Zou, D., Liu, Y., Zhu, B., and Li, X. (20 15). Effect of lipase addition on hydrolysis and biomethane production of Chinese food waste. Bioresour. Technol., 179, 452-459. http://dx.doi.org/10.1016/j.biortech.2014.12.015

Metcalf \& Eddy, Tchobanoglous, G., Burton, F.L., and Stensel, H.D. (2003). Wastewater Engineering: Treatment and Reuse, 4th Ed., McGraw-Hill, New York, 2003.

Parker, W.J. (2005). Application of the ADM1 model to advanced anaerobic digestion. Bioresour. Technol., 96(16), 1832-1842. http:// dx.doi.org/10.1016/j.biortech.2005.01.022

Pham, T.H., Rabaey, K., Aelterman, P., Clauwaert, P., De Schamphelaire, L., Boon, N., and Verstraete, W. (2006). Microbial fuel cells in relation to conventional anaerobic digestion technology. Eng. Life Sci., 6(3), 285-292. http://dx.doi.org/10.1002/elsc.2006 20121

Rittmann, B.E., and McCarty, P.L. (2001). Environmental Biotechnology: Principles and Applications, McGraw-Hill, New York.

Rodrigo, M.A., Cañizares, P., Lobato, J., Paz, R., Sáez, C., and Linares, J.J. (2007). Production of electricity from the treatment of urban waste water using a microbial fuel cell. J. Power Sources, 169(1), 198-204. http://dx.doi.org/10.1016/j.jpowsour.2007.01.054

Rosen, C., and Jeppsson, U. (2006). Aspects on ADM1 Implementation within the BSM2 Framework, Technical Report, Sweden, Dept. of Industrial Electrical Engineering and Automation Lund University.

Rozendal, R.A., Hameler, H.V.M., Euverink, G.J.W., Metz, S.J., and Buisman, C.J.N. (2006). Principle and perspective of hydrogen production through biocatalyzed electrolysis. Int. J. Hydrogen Energy, 31(12), 1632-1640. http://dx.doi.org/10.1016/j.ijhydene.20 05.12.006

Sasaki, D., Sasaki, K., Watanabe, A., Morita, M., Matsumoto, N., Igarashi, Y., and Ohmura, N. (2013). Operation of a cylindrical bioelectrochemical reactor containing carbon fiber fabric for efficient methane fermentation from thickened sewage sludge. Bioresour. Technol., 129, 366-373. http://dx.doi.org/10.1016/j.biortech. 2012.11.048

Sasaki, K., Hirano, S., Morita, M., Sasaki, D., Matsumoto, N., Ohmura, N., and Igarashi, Y. (2011). Bioelectrochemical system acelerates microbial growth and degradation of filter paper. Appl. Microbiol. Biotechnol., 89(2), 449-455. http://dx.doi.org/10.1007/ s00253-010-2972-x

Sasaki, K., Sasaki, D., Morita, M., Hirano, S., Matsumoto, N., Ohmura, N., and Igarashi, Y. (2010). Bioelectrochemical system stabilizes methane fermentation from garbage slurry. Bioresour. Technol., 101(10), 3415-3422. http://dx.doi.org/10.1016/j.biortech.2009. 12.076

Tartakovsky, B., Mehta, P., Bourque, J.S., and Guiot, S.R. (2011). Electrolysis-enhanced anaerobic digestion of wastewater. Bioresour. Technol., 102(10), 5685-5691. http://dx.doi.org/10.1016/j.bio rtech.2011.02.097

Tartakovsky, B., Mehta, P., Santoyo, G., Roy, C., Frigon, J.C., and Guiot, S.R. (2014). Electrolysis-enhanced co-digestion of switch grass and cow manure. J. Chem. Technol. Biotechnol., 89(10), 15 01-1506. http://dx.doi.org/10.1002/jctb.4224

Tice, R.C., and Kim, Y. (2014). Methanogenesis control by electrolytic oxygen production in microbial electrolysis cells. Int. J. Hydrogen Energy, 36(7), 3079-3086. http://dx.doi.org/10.1016/j.ijhy dene.2013.12.103

Wang, L., Liu, W., Kang, L., Yang, C., Zhou, A., and Wang, A. (2014). Enhanced biohydrogen production from waste activated sludge in combined strategy of chemical pretreatment and microbial electrolysis. Int. J. Hydorgen Energy, 39(23), 11913-11919. http://dx. doi.org/10.1016/j.ijhydene.2014.06.006

Wang, X., Cheng, S., Feng, Y., Merril, M.D., Saito, T., and Logan, B. E. (2009). Use of carbon mesh anodes and the effect of different pretreatment methods on power production in microbial fuel cells. Environ. Sci. Technol., 43(17), 6870-6874. http://dx.doi.org/10.10 21/es900997w

Yang, Y. H., Guergachi, A., \& Khan, G. (2006). Support vector machines for environmental informatics: application to modelling the nitrogen removal processes in wastewater treatment systems. $J$. Environ. Inform., 7(1), 14-25. doi: 10.3808/jei.200600063

Yeomans, J. S., Huang, G. H., \& Yoogalingam, R. (2003). Combining simulation with evolutionary algorithms for optimal planning under uncertainty: an application to municipal solid waste management planning in the regional municipality of Hamilton-Wentworth. J. Environ. Inform., 2(1), 11-30. doi: 10.3808/jei.200300014 